\begin{tabular}{l|ll}
\hline celeuma & número 4 | maio 2014 & cartas \\
\hline
\end{tabular}

\title{
'É UM LIVRO CANSATIVO'
}

20 de julho de 1919 Universitätsstrasse 29, Zurique

Prezada Senhorita Weaver: protelei minha resposta à sua carta porque esperava receber um telegrama ou uma carta de seus advogados, mas, como nada me chegou e estou perplexo, lhe escrevo agora. Você provavelmente descobriu entrementes que sou uma pessoa muito estúpida - um fato que eu teria preferido ocultar. Fui induzido em erro por certas afirmações ou alusões na última carta que seus advogados me enviaram tanto quanto pela minha própria interpretação equivocada do que aceitei por engano como uma pista a respeito do nome da minha benfeitora[1]. Se você estiver informada de que vivo em completa ignorância a respeito dos acontecimentos e das pessoas de Londres você se sentirá talvez inclinada a perdoar a minha estupidez. Raramente vejo um jornal ou um livro e não me correspondo com ninguém de lá sem contar com as cartas formais e as (agora muito raras) cartas do Sr. Pound. Não vejo por que razão eu deveria retirar as frases a que você alude mas vejo por que razão eu deveria, isso sim, aplicar a mim mesmo os epítetos opostos.[2]

Senti nestes últimos dias de espera nova sensação de perplexidade devido ao fato de que ao mesmo tempo em que tenho o grande prazer de saber que foi você que me ajudou e está me ajudando tão generosamente você me escreve que o último episódio enviado[3] parece revelar até certo ponto uma debilidade ou prolixidade. Depois do recebimento de sua carta reli esse capítulo muitas vezes. Levei cinco meses para escrevê-lo e sempre que termino um episódio minha mente mergulha num estado de completa apatia do qual parece que nem eu nem o meu livro deplorável jamais emergirão. O Sr. Pound me escreveu muito precipitadamente para desaprovar mas eu penso que a sua desaprovação está baseada em motivos que não são legítimos e é devida principalmente aos diversos interesses de sua admirável e enérgica vida artística. O Sr. Brock[4] também me escreveu pedindo-me que lhe explicasse o método (ou métodos) da loucura mas esses métodos são tão múltiplos, sofrendo 
variação de uma hora do dia para outra, de um órgão do corpo para outro, de episódio para episódio, que eu por mais que aprecie sua paciência crítica não poderia tentar oferecer uma resposta. Preciso lhe pedir que acrescente aos enormes favores que me tem feito também o da paciência. Se as Sereias foram consideradas tão insatisfatórias tenho pouca esperança de que Ciclope ou mais tarde o episódio Circe venham a ser aprovados: e, além do mais, me sinto incapaz de escrever esses episódios rapidamente. Os elementos necessários irão se fundir só depois de prolongada convivência. Confesso que é um livro extremamente cansativo mas é o único livro que sou capaz de escrever no momento.

Durante esses últimos dois anos em que recebi seus donativos sempre tive o pressentimento (que agora se provou falso) de que cada episódio do livro à medida que avançasse iria gradualmente alienar a solidariedade da pessoa que estava me ajudando. A palavra ardente endereçada a mim por seus advogados em resposta à minha inquirição [5] tem um significado peculiar para a minha mente supersticiosa não tanto por qualquer qualidade ou mérito na própria escrita como pelo fato de que o progresso do livro é de fato como o progresso de um jato de areia[6]. Logo que menciono ou incluo qualquer pessoa nele eu ouço sobre a sua morte, partida ou infortúnio: e cada episódio contínuo, tratando de algum ramo da cultura artística (retórica ou música ou dialética), deixa atrás de si um campo arrasado pelo fogo. Desde que eu escrevi Sereias sinto que me é impossível escutar qualquer tipo de música.

Tentei expressar minha gratidão a você mas não posso fazer dessa forma. Como você é a pessoa que levou o meu livro Retrato do artista quando jovem ao "conhecimento" do público ficarei muito grato se você aceitar o manuscrito daquele livro. Ele está em Trieste e, assim que as circunstâncias forem mais favoráveis, irei pegá-lo e enviá-lo a você.

Você me deu a ajuda mais generosa e oportuna. Gostaria de poder me sentir merecedor dela tanto como poeta quanto como ser humano. Tudo o que posso fazer é lhe agradecer. Muito atenciosamente seu James Joyce 
[2] Numa carta de 6 de julho, Harriet Weaver lhe escreveu, esclarecendo o mistério: "Talvez fosse melhor acrescentar que fui eu quem enviou a mensagem por intermédio dos srs.Monro, Saw\&Co. e que lamento tê-la mandado dessa maneira e na forma como o fiz. É bastante inibidor comunicar-se por intermédio de advogados. Receio que o senhor tenha de retirar todas as palavras sobre delicadeza e auto-obliteração. Posso apenas implorar que perdoe minha falta delas".

[3] Sereias.

[4] Crítico inglês A. Clutton Brock (1868 - 1924).

[5] Joyce indagou aos advogados a respeito da qualidade artística que o seu benfeitor ou benfeitora mais apreciaria em sua obra. Conforme a resposta que obtivesse, ele esperava descobrir se era um homem ou uma mulher.

[6] Equipamento destinado a lançar areia, em alta velocidade, sobre superfície metálica ou vítrea etc., ou para obter acabamento artístico, ou para remover pintura, ferrugem etc. (Dicionário Aurélio da Língua Portuguesa. Curitiba, Positivo, 2010.) 